\title{
The Dynamics of Education on the Development of an Intellectual Citizenry in Africa
}

\author{
Munyaradzi A. Dzvimbo \\ Department of Development Studies, Lupane State University, Zimbabwe \\ munyadzvimbo@gmail.com
}

\begin{abstract}
This article explores the importance of education and schooling precisely, as the catalyst for the development and transformation of citizens within, the African context. Historically, intellectual and citizenship education has always been seen as a western concept within the African continent. Hence, this exacerbated the myopic view that intellectual education is new as its approach in schools is often western oriented. Drawing from postcolonial theory, this study opines that though education and learning in particular have played a pivotal role in the enhancement and transformation of citizens in Africa as a whole during the post-independence era, citizenship education is not a new concept. Further, I expound and interrogate the African governments' efforts and initiatives in fostering citizenship through learning. More so, this study points out that if we do move beyond any labelling essentialities, intellectualism has always been part and parcel of the nucleus of education among these nations and schools have also served as catalyst of social change. This is clearly reflected in various tasks and projects found in educational policies and frameworks which include enhancing the provision and access to education, language policies, indigenous knowledge systems and the indigenisation of the school curriculum to enable it to be relevant to the current national ideals and vision. Conclusively, these programmes and initiatives were obviously implemented towards citizenship development aimed at empowering pupils with specific kind of education ideal for intellectual and national development within the countries of the Global South. Thus, the paper opines that the teaching of new learning areas through heritage studies in secondary schools, national and strategic studies in tertiary institutions should further be reconceptualised to reflect the local context and their ways of understanding and deconstructing the colonial narratives and mind set.
\end{abstract}

Keywords : colonial; citizenship; education; intellectual; policy

\section{Introduction}

Citizenship conceptually refers to membership to a country, and is legally anchored in the rights and responsibilities deriving from sovereign nation states (Osler and Starkey, 2003; Heater, 1990). In theory, citizenship education advocates for the citizenry to make their own decisions and to take responsibility for their own lives and their communities and it has acquired varied meanings nationally and internationally (Naval, Print and Veldhius, 2002; Omatseye and Omatseye, 2008). Generally, citizenship education gives people knowledge and skills to understand challenge and engage with the main pillar of democracy, politics and the economy (Crick Report, 1999; Kubow, 2007). Impressions emerging from the above seem to suggest that citizenship education is taught to preserve and challenge the status quo. Multifaceted the purpose maybe, the aims of citizenship education are summarily known to include the cultivation and development of civic virtues that enhance social responsibility, community involvement and political literacy among citizens. African scholars agree that, precolonial African citizenship education has been part of complete education of the young inducting them to become socially and culturally responsible and acceptable members of society (Preece and Mosweunyame, 2004; Peresuh, 1999). Colonial citizenship education had a metropolitan model that pushed individual prosperity instead of fostering nation building 
(Adeyemi, 2008). Citizenship education in most post-colonial African countries is infused in history and social studies which are believed to have the capacity to enhance and strengthen skills, values, knowledge and attitudes that are necessary for development responsible citizens (Nabudere, 2007; Yusuf, 2008; Ajiboye, 2008).

Africa is a vast continent with more than fifty countries that call for respect in its rich diversity in terms of background, languages, ethnicities, cultures and origins (Samoff, 1999). The 1950s and 1960s saw most of the African nations gain their independence from their colonial masters such that by 1960, 17 countries out of 53 nations had achieved sovereignty (Young, 2004; Samoff, 1999). At independence, these countries inherited institutional legacies from the colonial era because the authorities simply handed over their colonial culture without any consideration of the existing political culture in their countries. This posed a lot of problems since the political systems of the colonial masters were incongruent with the political culture of the diverse ethnic groups and their traditional social and economic heritages (Adeyemi and Asimeng-Boahene, 1999). The decolonisation era and the achievement of the independence by some African nations were a defining historical moment and a culmination of an epic struggle (Young, 2004). The decolonisation process was met with a sense of excitement, hope and anticipation as the new "states" appeared to shed the colonial legacy and reinvent them (Young, 2004; Samoff, 1999). As a result of decolonisation, the "new African states" were faced with a mammoth task of nation-building. Nation building is defined as process of creating a sense of national loyalty and identification among a population that has traditionally been divided into numerous tribes, ethnic groups or smaller political units (Adeyemi and AssimengBoahene, 1999). According to Young (2004) the notion of developing new states (nationbuilding) after pressure emanating from meeting the promises that were made during the anticolonial mobilisation and struggle. People had a lot of expectations as, the young militants who provided the muscle of nationalist movements expected opportunities for employment.

\section{Theoretical Underpinning}

This paper evolves from a post-colonial lenses to explore mainstream academic knowledge in post-colonial societies continue to ignore, marginalise and render other forms of knowing invisible. Post-colonial theory advocates for a number of issues in relation to education. These include decolonising knowledge and the production of transformative knowledge, mapping out manifestations of the power of countries of the Global North (GN) to the rest and locating how the dichotomous representation of the world establishes a rigid division uncivilised, and also challenges the discourse of nationalism (Subedi and Daza, 2008). This interrogative nature of post-colonial theory makes it undoubtedly an invaluable tool for the analysis and understanding of the perpetual legacy of colonialism and its forceful mechanisms " since the nineteenth century imperialism left very few places on earth untouched" (Said, 1993).

The marginalisation of Indigenous Knowledge Systems (IKS) that relegated all things indigenous as unworthy, uncivilised, barbaric and superstitious was established during the colonial era. Western forms of cultural, economic, political and social systems were institutionalised during the colonial period and continue to be maintained during the postindependence times (Chilisa, 2005). This study draws out of such concerns about how schools often reinforce or privilege Western forms of knowing and knowledge construction. African post-colonial scholars have argued that citizenship education as practiced has been imposed on 
Africans by Western countries without any considerations of their local cultures and contexts (Zvobgo, 1997; Sigauke, 2011). This in turn has made African education an elusive dream that draws largely from mainstream academic knowledge without any consideration of other diverse knowledge systems that prevail among these nations.

\section{Discussion}

\subsection{Reflection on Citizen Education in Africa}

New intellectuals emerging from universities expected guarantees of incorporation into the upper echelons of state bureaucracy, parents hoped that pledges of rapid school expansion even universal primary education, would materialise as well as social infrastructure promises in the provision of health and clinics, safe drinking water and roads will be delivered (Young, 2004). This seems to have been a tall order for the newly formed governments that needed to be attended in order to maintain the hope and excitement of epochal new in African politics. However, when African nations rid themselves of European colonial governments invested heavily in education at different levels, basically placing it at the centre, of the national project of social advancement and development. When we look at the African traditional setting citizenship education was perceived as a form of education that was used to initiate new members of the society through diffusion of their cultural heritage to the young in order to develop a feeling of national pride in people (Asmenge-Boahene, 2000; Mafela and Mgadla, 2000). The major aim of this indigenous citizenship education was to train individuals to be useful and acceptable in society.

\subsection{Reflection on Education and Development of Citizens in Africa}

In Africa, schools have been used to as instruments of social change (Verspoor, 2008; Stampf, 1996) and their main function has been to facilitate acceptance of change and to develop individuals with an inquiring attitude (Sachikonye, 1990; Zvobgo, 1997). Suffice to say, research conducted in Sub-Saharan Africa has shown that most of the curriculum and education policies adopted have failed to develop a critical mind in learners (Scanlon, 2002; Harber, 1997). On attainment of independence in 1980, for example Zimbabwe became preoccupied with preparation of citizenry in order to achieve socio-economic development and addressing past imbalances created by the colonial government (Matereke, 2011; Sigauke, 2012).The reforms were centred on the democratisation and de-racialization of the education system. Teaching experience with the Zimbabwean education system has shown that primary school curriculum integrated citizenship education mainly in the discipline of social studies. Features of the new history syllabi for the various secondary school levels, which came into force in 2003, were human rights and democratic issues, which are core and fundamental to citizenship education. Hence, as appealing as they maybe, human rights and democracy disciplines were never taught. This study argues that there are numerous ways in which schooling was used to develop "good citizens" among African nations and focus will be on the following: expansion and access of education, Educational policies, language policies, indigenous knowledge systems (IKS), Africanizing the curriculum and relevance to national ideals and values.

\subsection{Educational Expansion in Africa}

There was going to be the need for the development of citizenship through the expansion of access to education.Peresuh (1998)opines that the notion of expansion of access to education 
can be traced back to the mega trends that influenced and gave direction to the development of education in post-colonial Africa such as United Nations First Development Decade (19611971) which gave priority to the expansion of secondary and tertiary education and the conference of African States on the Development of Education in Africa (1961) which provided a forum for African countries to decide on their priorities in education to promote economic and social development. It was an all-African conferenceheld in AddisAbabain 1967 which cemented the importance of educational expansion (Stampf, 1996).It was at this conference that most African countries acknowledged the importance of education and resolved to provide "free universal primary education" by 1980 , secondary education to at least 30 per cent of those pupils who had successfully completed primary education to20 per cent of those candidates who had successfully completed primary education, and improving the quality of education at all levels of the education (Nabudere, 2007; Omatseye and Omatseye, 2008). The expansion of access to education was seen as a way to transform the society massively and rapidly, at the same time it was seen as a way in which governments could meet their citizens (Heater, 1990). This led to the opening of new schools in urban areas as well as in rural areas. Hence, African governments made a remarkable progress.

In 1990 governments of the Global South (GS), international and non-governmental organisations (NGOs) committed themselves to "Education for All" to a notable world conference in Jomtein, Thailand (Porta and Keating, 2008; Vespoor, 2008). The major themes of the Jomtein World Conference on "Education for All" were that education is a fundamental right; the key to personal and social improvement, and that basic education should therefore be provided to all (Waghid, 2009). Some African governments also committed themselves to providing "Education for All" to their citizens through increasing support for universal primary education (Delanty, 2000). Despite the good intentions by African governments, countries of the GS found themselves unable to meet their promises of providing education for all primarily because they did not have the financial muscle to execute those plans. Ajiboye(2008) is very critical about multi-lateral corporations and has referred to the state of affairs surrounding the discourse around 'development' as espoused by policies and programmes of the World, IMF and other multi-lateral development agencies as the new imperialism. Hence, it is vital to note that liberalisation has actually led to the collapse of expanded access to education as some countries cannot afford to educate.

\subsection{Dynamism of Indigenous Knowledge System (IKS)}

In most African countries there is a trajectory trend to resuscitate their heritage and culture through redirecting their national philosophies (Peresuh, 1999; Adeyemi; 2000). This has been effectively pursued through the inclusion and strengthening of Indigenous Knowledge Systems (IKS) in education specifically in countries like Kenya, Botswana, South Africa and Zimbabwe. In Zimbabwe, education revolves around the principles of democracy, indigenisation, entrepreneurship, development and self-reliance, which all are envisages in the ZIMASSET blueprint. Chikwanha (2009) posits that the notion of IKS's in the African context should entail that they develop into good citizens and their curriculum should further draw from their traditional African history and philosophy and teach African histories because in the case of South Africa and Namibia, history is in danger or precarious situation of disappearing and being extinct. IKS is defined as knowledge, values and practices of the local people who are synonymous with traditions in the indigenous communities who are occasionally seen as universal (Tendi, 2009). The study further extols that IK is based on intuition, experience, inspiration and explanation and that knowledge systems developed in African societies are 
composed of particular orientations to life, ethics, human development or progression and social relations.

Ubuntu is one example of an indigenous value system which is embodied in the African philosophy and traditional practices. Ubuntu refers to moral and cultural issues which encompass compassion, communalism, responsibility, patriotism and commitment of national issues (Ranger, 2005; Yusuf, 2008). In Zimbabwe for instance, Ubuntu has been holistically included within the new curriculum framework and spreads across all the five pillars of the ZIMASSET, the economic blueprint of Zimbabwe. The Zimbabwean government gives a working definition of Ubuntu as the concept of a well behaved, rounded character, who is also well mannered, behaved, courteous and disciplined with spark for ability to realise full ability both as individual and as part of the community one comes from (Ranchod, 2005; Nabudere, 2007). Furthermore, the ubuntu, uses a Zulu (language of an ethnic group in South Africa or cliché that implies "umuntu ngumentu ngabanto" (or individual is a person through other people) clearly showing that within the African situation a person's humanity is explained through sociability and that no individual will relax easily while being aware of another person's need. It is vital to note that IK is of paramount importance among Africans as it provides important information that is transparency and accountablewhile being inclined to the locality and indigenous (Nabudere, 2007). And in a way Africans have been taught to devalue and undermine each other. Hence, it is important to note that western values systems have been strengthened and embedded from Europe during the colonial era were spearheaded to serve and dismantle cultural values that were transmitted through informal and formal traditional schools and cultural tendencies (Mavhunga, Moyo and Chinyani, 2012).

\subsection{Africanisation of the School Curriculum}

Heritage or Social Studies and Religious and Moral Education (RME) espouse knowledge, skills, competencies, attitudes and societal values which enables the children to be disciplined citizens (Kubow, 2007; Hwami, 2012). The development of a committed citizen in Africa was done through the Africanisation of Heritage or Social Studies curriculum. In real sense, Africanisation is explained in the context of an African-centred education spiral that refers to the instruction and mandate that is developed from and centred on African people's experiences, thoughts, prejudice and conducive environments (Jansen, 1991; Hwami, 2013). This overview was cemented on the premise that the secondary school curriculum had to be changed to show the views and thoughts of Africans as opposed to those of the colonisers. The Africanisation of heritage or social studies were pursued in various ways and done in different dimensions of the curriculum which enabled the objectives, content and knowledge, values, attitudes and beliefs as well as the skills of the local people and indigenous people who are supposed to benefits. However, the current scenario calls for heritage studies curriculum to be revolutionised and modernised in line with the Africanisation of the whole discourse (Milner, 2002; Sigauke, 2012).

It has been noted that primary heritage and social studies curriculum in primary schools of most African countries including Malawi, Nigeria, Kenya, Botswana and Zimbabwe realised that, there should be a need to realign their curriculum to reflect and envisage their culture, language, living conditions and traditions (Crick Report, 1999). For instance, in Botswana and Kenya the idea to push towards Afro- Centric heritage studies included developing a strong moral code of etiquette and behaviour that is compatible with the ethics and traditions of Botswana and Kenya. In Zimbabwe, the new heritage studies syllabus put emphasis on the Zimbabwe's economic trajectory, cultural heritage and national political unity as well as the 
knowledge and appreciation of their local communities and the country as well. In the same realm, in Malawi more emphasis was put on teaching propaganda about the economic progress and its neighbours as compared to non-African continent (Nabudere, 2007). However, in Nigeria, the Africanisation of heritage or cultural studies were realised on the backdrop of local community, family, health, culture and economic well-being. Hence, the paradigm shift in the sense that the terms of the curriculum was inclined towards the transformation of ideal citizens who are concerned with their environmental set up which colonial education completely and wholly marginalised (Ndawi and Maravanyika, 2011; Mavhunga et al, 2012)

\subsection{Claims of Nationhood Developmental Needs}

Since the attainment of independence by most African countries from their colonial subjugation, they were faced with a mammoth task of nation building and education was foremost viewed as a transformative tool for development (Merryfield and Tlou, 1995; Moyo and Yeros, 2007). On the other hand, this was actually a predicament in that, African countries inherited oppressive and racially skewed educational systems with incapacitated human development capacity. However, in trying to correct these injustices and enhance transformation, dual contradictoryparadigmsevolved, one was based on the role of educationaltransformation, liberating and empowerment. In this regard, this perspective did put emphasis on the discourse which would assist pupils to conceptualise their societal values in order to transform and focus on innovation as well as experimentation (Nziramasanga, 1999). On the contrary, education was seen as skills development and preparation for the outside world. This overview puts emphasis on the enlightenment of students with specific skills to enable them to effectively suit into the human development market (Nabudere, 2007; Omatseye and Omatseye, 2008). Relevance to national needs entails viewing a minority perspective educational transformation in the lenses of empowering and liberating the citizenry. Another perspective became pronounced as shown by Education with Production (EWP) concept in Zimbabwe soon after independence in 1980. And education for self-reliance in Tanzania as well as production brigades in Botswana. In this regard, education was actually viewed as preparation and as the gateway to the world of work. Thus, students were supposed to be provided with effective relevant skills that would meet the needs of the labour market within the society (Milner, 2002; Naval et al, 2002).

Since the 1960s, when most African countries attained their independence, they have undergone grand metamorphosis and transformation to respond to the real needs and realities of their countries (Kubow, 2007). On the contrary, critics have objected the notion of relevance to the country's needs and aspirations which have been actually construed in terms of improving the standard of living and development of the continent's spiritual and material lives and this has led to schools limiting the learners' aspirations and ambitions as well as needs to be innovative and develop ideas for critical thinking and engagement. In this case intellectual education in Africa should not be an illusion but rather be a fundamental goal in live with the Sustainable Development Goals (SDGS) (Sigauke, 2012; Hwami, 2013).

\subsection{Perceptions of Intellectual Responsibility in Higher Education}

Hwami (2012) points out that the attainment of independence in most African countries such as South Africa and Zimbabwe has noticed that the education system never paid much attention to intellectual and citizen education in higher education. Most notably, a number of tertiary institutions in African countries are indirectly incorporating elements of intellectual and citizenship education in some of their programs. For example, intellectual enlightenment 
is found embedded in programs like Peace and Conflict Resolution, War and Defence Strategic studies. Consequently, Matereke (2011) posits that there is no obvious input to teach intellectual discourse and citizenship education as a separate program. Teaching experience and experiential contact with a number of academic personnel in universities has shown that even those who make efforts to teach programs of intellectual education in their programs try to do that out of their own volition. This is indeed evidenced by classical examples of universities and tertiary institutions in Botswana, South Africa and Zimbabwe (Hwami, 2012; Mavhunga et al, 2012). Most Southern African countries such as South Africa, Malawi, Zambia and Zimbabwe's higher education is well conceptualised in realm of tertiary education, inclusive of post-secondary education. There has been notable intellectual dispensation in universities and colleges which has accentuated political activism.

\section{Conclusion}

Apart from the above critical analysis, there is no doubt that schooling or higher education has been instrumental in the transformation of intellectual and citizenship education among African countries during post-independence era. It is also cemented in that citizenship education is similar with the intellectual discourse and is not new to the African continent. Suffice to say that, Africans have been made to think that it is a Western concept implying that there has been no attempts to reconceptualise intellectual education in schools and tertiary institutions taking into consideration the socio-cultural connotations and imperatives of these African countries. Intellectual and citizenship education prevailed to be taught from compromised Eurocentric lenses with minimal or no recognition of the beneficiaries. This perception calls for data and knowledge that is inclined towards re-writing our Afro-histories, strategic and heritage studies as well as knowledge systems with the aim to reinstate our African ideology and identity. It is in the African countries to reorganise and reinvent themselves, their socio-historical issues, cultures and customs and advocates for developmental African renaissance in the realm of developing a progressive citizenry with the ideal intellect to holistically enhance and improve African and global foothold.

\section{References}

Adeyemi, M.B and Asimeng-Boahene, L. (1999). Junior secondary social studies programme and nation building in Botswana. New horizons in education: The journal of world education fellowship, 11, 27-42.

Adeyemi,T.O. (2008). Teachers, Teaching Experience and Students, Learning Outcomes in Secondary Schools in Ondo State, Nigeria. Asian Journal of Information Technology 7(5), 201-209.

Ajiboye, J.O (2008). Enhancing Botswana children's environmental knowledge, attitudes and practices through civic clubs. International journal of environmental and science Education 3(3), 105-114.

Chikwanha, A.B. (2009).Higher Education and student politics in Zimbabwe.In D.P.Chimanikire (Ed), Youth and higher education in Africa(79-108). Dakar: CODESRIA. 
Chilisa, B. (2005). Educational research within postcolonial Africa: a critique of HIV/AIDS research in Botswana. International journal of qualitative studies in education, 18(6), 659684.

Crick Report (2008). Education for Citizenship and the Teaching of Democracy in Schools, London.DfEE.

Delanty, G. (2000). Citizenship in a Global Age: Society, Culture, Politics. Buckingham, Open Press.

Heater, D. (1990).Citizenship: The Civic Ideal in World History, Politics and Education. Harlow, Longman.

Hwami, M. (2012).Towards a Critical Colonial Analysis of the Crisis in Higher Education in Zimbabwe: A Case Study of the University of Zimbabwe. Spring Edmonton, Alberta.

Hwami, M. (2013).The "Nativist Turn" and the Crisis in University Education.In Zimbabwe International Journal of Education, 5(4).

Jansen, J. (1991). The State and the Curriculum in Transition to Socialism: The Zimbabwean experience, Comparative Education Review, 35(1) 76-91.

Kubow, P.A. (2007). Teachers' constructions of democracy: intersections of western and indigenous knowledge in South Africa and Kenya. Comparative education review, 51(3), 307-328.

Mafela, L. \&Mgadla, P.T. (2000).The historical context of education in British colonial Africa.In M.B. Adeyemi (Ed).Social studies in African education, 1-10.Gaborone: Pyramid.

Matereke, P. (2011). Whipping into line: The Dual Crisis of Education and Citizenship in Post-Colonial Zimbabwe. In Educational Philosophy and Theory: Philosophy of Education Society of Australia. 44. (2) 84-99.

Mavhunga, P.J, Moyo, N. and Chinyani, H. (2012).Towards a Citizenship Education for Zimbabwe. In Zimbabwe Journal of Educational Research, 24 (1).

Merryfield, M.M. \&and Tlou, J. (1995). The process of Africanizing the social studies.Social studies, 86(6), 1-19.

Milner, H. (2002). Civic Literacy: How Informed Citizens Make Democracy Work, Hanover, NH, University Press of New England.

Moyo, S. and Yeros, P. (2007). "Intervention: The Zimbabwe question and the two lefts", Historical Materialism, 15 (3): 171-204.

Ndawi, O.P and Maravanyika, O.E. (2011).Curriculum and its Building Blocks.Concepts and Processes. Gweru, Mambo Press.

Nabudere, D.N. (2007). The developmental state in Africa.Journal of Southern African Review of Education (SARE), 13(2), 125-138.

Naval, Print and Veldhius (2002). Citizenship Education and Social Studies in Singapore: A National Agenda. International Journal of Citizenship and Teacher Education, 1(1)6.

Nziramasanga, C.T. (1999). Presidential Commission (1999) Report on the Zimbabwean Education, Government Printers, Harare.

Omatseye, J.N. and Omatseye, B.O. (2008).Going to school in sub-Saharan Africa.Connecticut: Greenwood press.

Osler, Aand Starkey, H. (2003).Learning for citizenship debates and young people's experiences. Educational review, 55(3).

Peresuh, M. (1998). Post- Independence Education in Zimbabwe: Achievements, Constraints and the Way Forward. Journal of Practice in Education for Development, 3(3)129136. 
Peresuh, M. (1999). Traditional Education: Context, Functions and Importance, M. Peresuh and T. Nhundu (Eds) Foundations of Education for Africa (Harare, College Press).

Preece, J. and Mosweunyane, D. (2004).Perceptions of Citizenship Responsibility Amongst Botswana Youth, Gaborone, Light Books.

Porta, D.D and Keating, M. (ed). (2008). Approaches and Methodologies in the social sciences.A pluralist perspective. Cambridge Press, Cambridge.

Ranchod, K. (2005). Citizenship and Identity, Brain Drain and Forced Migration: The case of Zimbabwe, Policy Issues and Actors, 18(3), 1-22.

Ranger, T. (2005).The Uses and Abuses of History in Zimbabwe.In M. Palmberg and R. Primorac (Eds), Skinning the Skunk-Facing Zimbabwe's Futures, Discussion Paper 30 (Uppsala, NordiskaAfrika Institute, 7-15.

Sachikonye, L.M. (1990). 'The 1990 Zimbabwe, Elections: A Post-Mortem', Review of African Political Economy, 48; (1999), Restructuring or De-Industrializing Textile and Metal Industries Under Adjustment, Uppsala: NAI; (2000), The Year of Zimbabwe's Political Watershed', Southern African Political and Economic Monthly, 14(3).

Sigauke, A.T. (2011). Citizenship and citizenship education: a critical discourse analysis of Zimbabwe presidential commission report, citizenship teaching and learning, 6(3), 260-285

Sigauke, A.T. (2012). Young People, citizenship and citizenship education in Zimbabwe, international journal of educational development, 32(2), 214-223

Said, E.W. (1993).Culture and imperialism.London:Chatto and Windus.

Samoff, J. (1999). No teacher, no textbooks, no chairs: Contending with crisis in African education. Prepared for presentation at the 43rd Annual Meeting of the African Studies Association, Philadelphia, 11-14 November.

Stampf, R.H. (1996). The development of education in postcolonial Africa. Pretoria: Human Sciences Research Council (HSRC).

Subedi, B. and Daza, S.L. (2008). The possibilities of postcolonial praxis in education.Race ethnicity and education, 11(1), 1-10.

Tendi, M. (2009).Becoming Zimbabwe teaching history in context in Zimbabwe, Institute of Justice and Reconciliation, Compress, South Africa.

Vespoor, A.M. (2008). The challenge of learning: Improving the quality of basic education in sub-Saharan Africa. In J.David (Ed).The changing landscape of education in Africa.Oxford studies In comparative education, 19 (1), 14-43.

Waghid, Y. (2009). Patriotism and Democratic Citizenship Education in South Africa: On the (im) possibility of Reconciliation and Nation Building, Educational Philosophy and Theory, 41 (4) 399-409.

Young, C. (2004). The end of the post-colonial state in Africa?Reflections on the changing African political dynamics.African Affairs, 103, 23-49.

Yusuf, A. (2008). Citizen education: An instrument for unity and stability in Nigeria. In A.R. Yusuf, A.S Agbona, A. Jekayinfa and A. Saliu.The effects of citizenship education component of social studies Ilorin metropolis, Nigeria.African journal of political science and international relations, 5(9), 427-441.

Zvobgo, R.J. (1997). State, Ideology and Education. Gweru, Mambo Press. 